\title{
MICROBIAL CONTAMINATION OF STORED HYDROCARBON FUELS AND ITS CONTROL
}

\author{
Christine C. Gaylarde ${ }^{*}$, Fátima M. Bento ${ }^{2}$, Joan Kelley ${ }^{3}$ \\ ${ }^{1}$ MIRCEN, Departamento de Solos, Faculdade de Agronomia, Universidade Federal do Rio Grande do Sul- \\ UFRGS, Porto Alegre, RS, Brasil. ${ }^{2}$ Departamento de Metalurgia, Universidade Federal do Rio Grande do \\ Sul, Porto Alegre, RS, Brasil. ${ }^{3}$ International Mycological Institute, Bakeham Lane, Egham, Surrey, UK
}

\section{MINI-REVIEW}

\begin{abstract}
The major microbial problem in the petroleum refining industry is contamination of stored products, which can lead to loss of product quality, formation of sludge and deterioration of pipework and storage tanks, both in the refinery and at the end-user. Three major classes of fuel are discussed in this article - gasoline, aviation kerosene and diesel, corresponding to increasingly heavy petroleum fractions. The fuel that presents the most serious microbiological problems is diesel. The many microorganisms that have been isolated from hydrocarbon fuel systems are listed. The conditions required for microbial growth and the methods used to monitor and to control this activity are discussed. The effects of various fuel additives, including biocides, are considered.
\end{abstract}

Key words: Biocides; biofilms; hydrocarbon fuels; microbial corrosion; storage tanks

\section{INTRODUCTION}

The petroleum refining industry is one of the largest manufacturing industries in the world. After Western Europe and the USA, Latin America, including Mexico, has the highest refining capacity of the rest of the world. Huge amounts are spent each year on capital equipment, modernization and maintenance, including prevention and treatment of microbial contamination. The major microbial problem in the industry is contamination of stored products, which can lead to loss of product quality, formation of sludge and deterioration of pipework and storage tanks, both in the refinery and at the end-user. Reports of such contamination have increased substantially in recent years $(25,26)$, probably due to increasing demand for diesel fuel and high quality gasolines and jet fuel (4).

Crude oil is a mixture of many different hydrocarbons, straight, branched and cyclic aliphatics, aromatic and heterocyclic compounds. The composition varies with the origin of the oil; heavy crudes generally have high carbon, metal and asphaltene content and are less stable chemically than lighter crudes. The refining process can be divided into four phases: 1) separation, 2) cracking, 3) chemical reactions such as polymerization or alkylation, 4) blending. Refinery products are mixtures of compounds. Gasoline, for example, contains straight chain and branched-chain

\footnotetext{
* Corresponding author. Mailing address: MIRCEN, Departamento de Solos, Faculdade de Agronomia, UFRGS, Caixa Postal 776, CEP 91000970, Porto Alegre, RS, Brasil. Fax (+5551)316-6026. E-mail: chrisg@vortex.ufrgs.br
} 
hydrocarbons, alkenes, naphthalenes, aromatics and other compounds. Stabilizers, octane enhancers (principally tetraethyl lead), anti-corrosion agents and other substances may also be added. Treatments such as desalting, dehydrating and desulfurization are also sometimes required. The processes employed in fuel production affect the composition of the final product, which, in turn, affects its susceptibility to microbial contamination.

\section{CHARACTERISTICS OF HYDROCARBON FUELS}

Three major classes of fuel are discussed in this article - gasoline, aviation kerosene and diesel, corresponding to increasingly heavy petroleum fractions (Table 1).

Table 1 - Fuel fractions obtained from crude oil

\begin{tabular}{lll}
\hline Fraction & C atoms & M. Wt. \\
\hline Gas & $1-4$ & $16-58$ \\
Gasoline & $5-12$ & $72-170$ \\
Kerosene & $10-16$ & $156-226$ \\
Diesel & $15-22$ & $212-294$ \\
\hline
\end{tabular}

Gasoline The properties of the various grades of gasoline are controlled by specifications designating boiling point range, volatility, octane number, stability and various minor constituents. Sulfur compounds, consisting mainly of disulfides, sulfides and thiophenes, are undesirable and the level is rarely above $0.25 \%$ wt. Various additives are allowed:-

- anti-oxidants (e.g., substituted aromatic amines and phenols). These remove free radicals, which cause the production of polymeric gums

- metal deactivators (chelating agents such as disalicylal-1,2-propane diimine), which inhibit the formation of free radicals

- tetraethyl or tetramethyl lead (anti-knock compounds)

- anti-icing agents (alcohols or surfactants)

- corrosion inhibitors (surfactants).

Dyes may also be added for identification and advertising purposes. In Brazil, gasoline may contain up to $17 \%$ alcohol. This would be expected to concentrate in the water phase, inhibiting microbial growth. The range of carbon chain lengths present in gasoline (Table 1) also limits growth of microorganisms, the lower molecular weight compounds may be toxic due to the solvent effect on cell membranes (31). However, it is apparent that many of the allowed additives (e.g., surfactants) could act as nutrient sources for microorganisms, whilst others, like the anti-knock compounds and sulfur containing compounds, may be slightly inhibitory.

Jet Fuel. Specifications for jet fuel (aviation kerosene) are the most demanding. The fuel must ignite readily under all conditions and must burn steadily with no blowout or flashback. It must produce minimal levels of particulates and must have low vapor pressure and freezing point (9). These requirements are met by paraffinic kerosene or a mixture of kerosene and gasoline fractions with an aromatic content below 25\%. Anti-icing agents (diethylene or triethylene glycol monomethylether; 2methoxyethanol 2-ME) may be added to the fuel and these have a biostatic activity (32), although Pseudomonas putida has been shown to utilize 2ME (15). The hydrocarbons in this fuel are readily degraded by some microorganisms.

Diesel. Diesel fuel is a hydrocarbon product boiling between approximately $150^{\circ} \mathrm{C}$ and $400^{\circ} \mathrm{C}$, with carbon chain lengths of $\mathrm{C} 15-\mathrm{C} 22$ (Table 1). Various classes are available and classification differs from country to country. Some classes contain selected cracked distillates such as light cycle oils (10). In Brazil, a relatively new introduction onto the market is "urban (or metropolitan)" diesel, which has a lower permitted level of sulfur $(0.5 \%$ maximum, somewhat higher than in many other countries). Reduced sulfur content can allow enhanced microbial activity. Marine diesel fuel differs in its specifications from others. In Brazil, it must reach its flash point in 60 , rather than 30 , minutes. A variety of additives may be used to improve the stability of the fuel; these include compounds such as aliphatic amines, chelating agents, detergents and corrosion inhibitors (4), some of which can act as a nutrient source for microorganisms. Diesel is the fuel which suffers from the most varied microbial contamination problems.

\section{CONTAMINATION PROBLEMS IN FUEL STORAGE TANKS}

Even in the best-kept tanks, microbial contamination is an occasional problem. Microorganisms are usually present in the fuel, but good housekeeping (removal of water and use of biocides) minimizes their growth. Nevertheless, reports of microbial growth in fuel tanks have increased in the last few years (26) and the holding of strategic reserves for long periods has always been problematical (12). The most important requirement 
for microbial growth in fuels is water. This is almost always present, for the following reasons:

- water dissolved in the fuel can condense on tank walls

- moisture in the air can enter through floating tank lids or other vents

- poorly designed tanks do not drain efficiently

- water may be added as ballast (on ships) or to purge the delivery system.

In Brazil, the specification for diesel oil allows a maximum of $0.05 \%$ water. This is $0.5 \mathrm{ml} /$ litre - quite sufficient for the initial growth of microorganisms. Although Hill and Hill (26) state that 1\% water is needed for substantial microbial growth, a fine film of water on the tank surfaces, or a few microliters in the fuel, is enough to allow microorganisms to begin growing, and cell metabolism, once begun, results in the production of more water. Thus the cycle continues.

Oxygen is normally present in sufficient quantities in distillate fuels (25), and is continually replenished when tanks are refilled. However, even if the fuel becomes anaerobic, it is not protected from microbial attack, since facultative organisms, such as Bacillus, and anaerobes, such as sulfur-reducing bacteria (SRB), continue to thrive. The limiting factor to growth is probably availability of minerals, particularly phosphorus, which is generally present at $<1 \mathrm{ppm}$ in the fuel (25). Nitrogen and iron may also be important limiting nutrients (48). Many laboratory-based studies have shown that fungi grow much more readily in a fuel system containing mineral salts solution as the aqueous phase than with water, or even tank drainage water (6). However, apart from minerals entering in water or aerial contaminants, many of the additives now used in the fuel industry contain these vital mineral elements, removing one of the factors that limited growth in earlier times.

Problems associated with microbial growth are listed in Table 2. In diesel fuel, microbial contamination may contribute to aging instability (28), but in general the most important consequences are microbially induced corrosion of the storage tanks and pipework, and formation of microbial mats, with the ability to block filters and pipelines, and to increase wear in pumps. According to Irish and Richardson (27), as little as $1 \mathrm{mg}$ particulates $/ 100 \mathrm{ml}$ fuel can cause filtration problems. In addition to microorganisms, these may include dirt, dust, sand, components of other filters such as paper or cotton, pump wear particles, corrosion debris and material removed from tank or pipe linings, such as fiberglass

Table 2 - Consequences of microbial growth in fuel systems

\begin{tabular}{ll}
\hline Problem & Principal types of microorganisms \\
\hline $\begin{array}{l}\text { Blockage of pipes, valves, filters and incorrect readings } \\
\text { from fuel probes }\end{array}$ & Fungi; polymer-producing bacteria \\
Increased water content & All \\
Sludge formation & All \\
Surfactant production, causing oil/water emulsification, entry & Fungi and aerobic bacteria \\
$\quad$ of cells into the oil phase and coalescer malfunction & \\
Corrosion of storage tanks and lines & Fungi and anaerobic bacteria \\
Production of suspended solids in the fuel & All \\
Breakdown of hydrocarbons & Fungi and aerobic bacteria \\
Shortened filter life & All \\
Fouling of injectors & Aerobic bacteria and fungi \\
Increased sulfur content of fuel & SRB \\
Shortened life of engine parts & Undetermined \\
Penetration of protective tank linings & Fungi \\
Health problems & Endotoxin-producing bacteria, \\
& opportunistic pathogens, SRB. \\
\hline
\end{tabular}

Sources: 5, 14, 25, 26, 36, 40, 42, 55 . 
(54). Corrosion from within tanks and pipelines can be intense when microbial contamination is present.

In aircraft fuel tanks, made of aluminum alloys, Hormoconis resinae can be a major problem causing corrosion and/or penetration of tank linings. Airlines are aware of this and regular testing is undertaken. Current tests however require a minimum of 24 hours and there are still financial implications involving downtime and clean up operations when contamination is found. The major microorganisms involved in storage tank corrosion are the anaerobic SRB. Aerobic bacteria may also participate in the process (for descriptions of microbially influenced corrosion, see refs. 16, 51). Fuel storage tanks inground are especially prone to contamination problems, because of the difficulties of drainage. Since they are hidden from view, it may not be noticed that they are corroded and leaking and thus important environmental pollution can result. In Brazil, many fuel distribution stations are replacing in-ground tanks by aerial ones, with resulting decrease in microbial problems. There are, of course, other hazards associated with aerial tanks, such as increased fire risk. A new regulation in the USA requires in-ground tanks to be protected against corrosion by a variety of mechanisms (coatings and cathodic protection), which will mean considerable expenditure by the firms involved.

Microorganisms may enter the fuel from the soil, via the air, from polluted wash water, contaminated pipelines, or from the biofilm present on the tank walls, if the latter have not been sufficiently well cleaned. Table 3 shows the organisms which have been isolated from various stored hydrocarbon fuels. Not all of these organisms are capable of metabolizing hydrocarbons. Those that have been reported to grow, rather than simply survive, in fuel are marked with an asterisk. Apart from the hydrocarbons, organisms may gain nutrients from fuel additives, from dirt entering the system, or from the growth of primary colonizing organisms. The hydrocarbon chains most readily utilized are C10-C18. Shorter chain hydrocarbons may actually inhibit growth of some organisms. Different strains of $H$. resinae however have been reported as having different optimal chain lengths for growth. Teh and Lee (47), using isolates obtained from soil in Australia by the 'Creosoted matchstick technique' (34), found highest yields on n-alkanes C13-C18. Cafone et al. (8) studied two isolates from jet fuel and found these to have optimum growth at chain length $\mathrm{C} 11$. This may reflect the alkane chain lengths in the substrate from which the fungi were isolated, creosote containing the longer chains from approximately C12-C24.

To assess the importance of particular microorganisms in fuel deterioration, it is essential to determine their ability to grow, rather than merely exist, in these systems. Unpublished studies at UFRGS indicate that $H$. resinae and $A$. fumigatus isolated from diesel are able to grow in Bushnell-Haas mineral medium plus diesel as sole carbon source, whilst $P$. variotii grows poorly, if at all. Hettige and Sheridan (23) showed that $H$. resinae, $P$. corylophilum and $P$. variotii all grew in this system, when inoculated separately, whilst in mixed cultures of $H$. resinae and $P$. corylophilum, only $H$. resinae remained viable after 6 weeks. P. corylophilum was, however, able to grow in Bushnell-Haas/fuel from which $H$. resinae had been removed by filtration, indicating that it does not compete well in terms of growth, but is not inhibited by $H$. resinae metabolites. More work is needed to define those microorganisms from the above list (Table 2) which are able to utilize the hydrocarbon chains, and those that grow on other fuel components.

\section{Importance of fuel additives}

It has been suggested that microbial growth in gasoline occurs only at the expense of additives such as vegetable oil phosphatides, and certainly largescale microbial contamination is seen only in the presence of organic additives (11). Solana and Gaylarde (45) found that $H$. resinae grew in gasoline containing $13 \%$ alcohol for only 6 days after inoculation, but that changes in the hydrocarbon composition were, nevertheless, produced. It is also rare to find SRB as gasoline contaminants, but this may be due to the toxic effect of gasoline hydrocarbons (11). The presence of various additives in diesel oil has been held responsible for increased microbial problems, but recent work at UFRGS suggests that certain new additives have no effect on fungal growth (6). It is important to test agents intended to improve chemical and physical fuel properties for their potential as stimulators of microbial growth. Utilization of an additive by microbial cells not only results in increased contamination problems, but also leads to "neutralization" (by breakdown) of the additive itself. Chromium tables introduced to naval fuels to enhance anti corrosive properties were found to act as excellent substrates for growth of chromium resistant strains of fungi, due to the degradable binders used in the tables (Kelley, Unpublished). 
Table 3 - Microorganisms isolated from fuels

\begin{tabular}{|c|c|c|}
\hline \multicolumn{3}{|l|}{ Bacteria } \\
\hline Acinetobacter* & Brevibacterium ammoniagenes & Pasteurella sp. \\
\hline Acinetobacter calcoaceticus & Clostridium sporogenes & Pseudomonas sp.* \\
\hline Acinetobacter cerificans & Corynebacterium sp. & Pseudomonas aeruginosa* \\
\hline Actinomycetes & Enterobacter cloacae & Pseudomonas fluorescens \\
\hline Aerobacter aerogenes & Enterobacter glomerans & Pseudomonas maliphora \\
\hline Alcaligenes* & Flavobacterium arborescens & Pseudomonas oleovorans* \\
\hline Bacillus sp.* & Flavobacterium diffusum & Pseudomonas putida* \\
\hline Bacillus acidocaldarius & Micrococcus sp. & Serratia marcescens \\
\hline Bacillus megatherium & Moraxella sp. & Serratia odorifera \\
\hline Bacillus subtilis & Ochrobactrum anthropii & $\mathrm{SRB} *$ \\
\hline \multicolumn{3}{|l|}{ Yeasts } \\
\hline Aureobasidium pullulans & Candida guilliermondii* & Candida zeylanoides \\
\hline Candida sp.* & Candida lipolytica* & Hansenula mrakii \\
\hline Candida famata* & Candida rugosa & Rhodotorula sp.* \\
\hline Candida fluviatilis & Candida tropicalis & Saccharomyces sp. \\
\hline \multicolumn{3}{|l|}{ Filamentous fungi } \\
\hline Acremonium sp. & Fusarium sp.* & Penicillium hirsutum \\
\hline Acremonium strictum* & Fusarium acuminatum & Penicillium minioluteum \\
\hline Alternaria sp. & Fusarium moniliforme* & Penicillium notatum\# \\
\hline Alternaria alternata & Fusarium oxysporum* & Penicillium spinulosum \\
\hline Aspergillus sp. ${ }^{*}$ & Fusarium sambucinum & Penicillium thomii \\
\hline Aspergillus clavatus & Geomyces cretaceus & Penicillium waksmanii \\
\hline Aspergillus fischeri & Geotrichum candidum & Pestalotiopsis aquatica \\
\hline Aspergillus flavus & Gliomastix sp. & Phialophora sp. \\
\hline Aspergillus fumigatus* & Helminthosporium sp. & Phialophora richardsiae \\
\hline Aspergillus niger* & Hormoconis resinae* & Phoma sp. \\
\hline Aspergillus nidulans & Humicola grisea & Phomopsis sp. \\
\hline Aspergillus ochraceus & Mucor sp & Pseudallescheria boydii \\
\hline Aspergillus paradoxus & Paecilomyces sp. & Rhinocladiella sp. ${ }^{*}$ \\
\hline Aspergillus sejunctus\# & Paecilomyces lilacinus & Rhizopus oryzae \\
\hline Aspergillus sydowi & Paecilomyces variotii* & Sordaria fimicola \\
\hline Aspergillus versicolor & Paecilomyces virvus & Stemphylium botryosum \\
\hline Aspergillus tamarii & Penicillium sp.* & Thielavia sp. \\
\hline Botrytis cinerea & Penicillium brevicompactum & Trichoderma sp. \\
\hline Cephalosporium sp. & Penicillium canescens & Trichoderma harzianum \\
\hline Chaetomium dolichotrichum & Penicillium citrinum & Trichoderma koningii \\
\hline Chaetomium globosum & Penicillium corylophilum* & Trichoderma viride* \\
\hline Cladosporium sp. & Penicillium cyclopium*\# & Trichosporon sp.* \\
\hline Cladosporium cladosporoides* & Penicillium digitatum & Trichothecium roseum \\
\hline Cladosporium herbarum & Penicillium echinulatum & Tritirachium oryzae \\
\hline Cladosporium sphaerospermum & Penicillium expansum & Ulocladium sp. \\
\hline Curvularia lunatus & Penicillium frequentans\# & Ulocladium atrum \\
\hline Drechslera cynodontis & Penicillium funiculosm & Ulocladium chartarum \\
\hline Epicoccum purpurascens & Penicillium glabrum\# & \\
\hline
\end{tabular}

* organisms with reported ability to grow in fuel

\# Synonyms:-

Aspergillus sejunctus $=$ A. rubrobrunneus, Penicillium frequentans $=P$. glabrum, P. cylopium $=$ P. aurantiogriseum, P. notatum $=P$. chrysogenum Sources: 1,$2 ; 5, ; 7,11,13,15,16,19,21,23,24,30,33,35,37,40,41,43,44,49,50,52,53,54$, and IMI Genetic Resource Collection Records. 


\section{Fuel testing for microbial contamination}

Tests for the presence of microorganisms in fuels include filtration accompanied by microscopy and/ or culture, direct culture of fuel or drained water samples and newly developed and developing immunological methods. For details of traditional techniques, reference may be made to textbooks, manuals and various published papers (e.g., 22, 26, 33, 39). In 1979, Bailey and May (3) examined the use of commercially available kits for detection of contamination in marine diesel and found that most gave results correlating well with standard plate counts. They detected $<50$ to $10^{3}$ bacteria/ml fuel and $10^{2}$ to $10^{6}$ bacteria/ml seawater ballast, with corresponding fungal counts of 0 to $<10$ and 20 to $10^{2}$. SRB were only detected in the water phase, an observation confirmed in studies in Brazil (5). Detection of SRB is an especial cause for concern because of their role in corrosion and production of the toxic gas, hydrogen sulfide. Hill and Hill (26) state that expected numbers of microorganisms per milliliter of the water bottom from slightly (highly) contaminated fuels are $10^{5}\left(10^{6}-10^{8}\right)$ bacteria and $10^{3}$ $10^{4}\left(10^{4}-10^{6}\right)$ yeasts/fungi, although the validity of using viable counts as an indicator of contamination by filamentous fungi in any situation is perennially contentious. It is extremely important to test the drained water sample and not merely the fuel itself, since the majority of contaminants will be present in this aqueous phase, or at the fuel/water interface. A clean fuel will contain less than 50 organisms per liter, whilst the associated water may carry $>1,000$ or $>40,000$ organisms per milliliter (25). A "rapid" detection method much used for jet fuel in Brazil is the Boron Microbe Monitor Test, in which fuel samples are incubated over an aqueous mineral salts layer with or without biocide. A positive result is one in which a change at the interface (fungal growth) is noted in the non-biocide-containing flask. This method, although simple to perform and interpret, is slow to produce results (1-2 weeks are generally required). Commercially available rapid on site kits were assessed by Stockdale and Watkinson (46) and a recently developed rapid immunofluorescence method to specifically detect Hormoconis resinae is described by Lopes and Gaylarde (29). This highly sensitive technique can be performed in half a day, a considerable improvement on current methodologies.

It should be noted that it is not necessary to detect viable cells to indicate a potential problem. Microbial metabolic products (e.g., acids, polysaccharides, surfactants) are also important contaminants and can be tested for by simple methods, or mere observation.

Standards - No acceptable standards have been published for microbial contaminants in fuels (26). Standards have been established using figures based on direct visual counts of fungal fragments; this an unsatisfactory and labor intensive technique. Standards based on colony forming units (especially when filamentous fungi are involved) are not acceptable because they do not correlate directly with genuine contamination and can only give estimates of the size of any problem. With the development of new rapid methods where vital activities can be measured more closely, the concept of an acceptability standard may become achievable. A number of companies use "inhouse" standards for quality control of their products, but a recognized upper limit for numbers of the various classes of microorganisms does not exist. Hartman et al. (20) suggested a classification of risk factors for stored jet fuel into "low", "medium" and "high", based on number of moulds, number of aerobic bacteria, number of SRB, COD, $\mathrm{pH}$, Eh, sulfate level and sulfide concentration. These parameters, measured in bottom and upper layers, were supplemented with chemical measurements of water separation index, water tolerance, elemental sulfur, hydrogen sulfide, copper and silver corrosion rates and total acidity to produce a Computerized Expert System for diagnosis and control of fuel storage systems. The recommendations for any necessary action were based on:-

- overall microbial activity

- overall risk of chemical deterioration

- microbial contamination in the upper level (i.e., the fuel phase)

- type of roof on the tank (fixed or floating)

- previous history

- water accumulation potential of the tank (diesel)

Once a decision to take remedial action has been made, the type of treatment must be selected. This will almost certainly involve emptying the tank and taking it out of service for a period, with concomitant economic losses.

\section{CONTROL OF MICROBIAL CONTAMINATION}

As in most cases of microbial biodeterioration of materials, the best control treatment is prevention. Cleanliness and frequent drainage of water should ensure that problems are minimal. However, these standards are difficult to maintain in practice and it is not infrequent that storage systems have to be emptied 
for thorough cleaning (removal of biofilms) and biocides used. Corrosion induced in the tanks may be avoided by internal coatings, which will be effective for some years, but this is an expensive option, albeit one which is increasingly employed. Cathodic protection (impressed current or the use of sacrificial anodes) is also used to combat corrosion, sometimes in addition to resistant coatings. Although expensive, this may be less costly than the government-imposed fines which are levied in the USA against companies polluting the environment with leaked fuels. Such provisions, however, do not reduce the other consequences of contamination. Without adequate drainage, microbial slimes and sludges are likely to form in fuel systems and hence recourse to biocides may be necessary.

\section{Selection of biocides for use in fuel systems}

The criteria governing the selection of an effective biocide formulation can be summarized as follows:

- no adverse effects on fuel specifications (ref 35 lists the parameters which should be unaffected)

- no adverse effects on engines, pumps etc.

- efficacy against a broad spectrum of microorganisms

- ability to penetrate microbial slime

- chemical and physical compatibility with the fuel and other additives (e.g., corrosion inhibitors)

- suitable partition coefficient (water-oil)

- safety and ease of use and storage

- biodegradability

- cost-effectiveness.

In aircraft fuel systems, routine maintenance, rigorous monitoring and treatment with allowed biocides when necessary (EGME [in military aircraft], organoborinane, or isothiazolone [which is allowed by some manufacturers]) keep risks of serious microbial growth to a minimum. Other fuels are generally not so well protected, but a wider variety of biocides is available. These include formulations intended to partition into the fuel phase and other, water-soluble, compounds. It is generally recommended that the biocide dissolve in the oil and then partition into the aqueous phase in sufficient quantity to protect the whole system and not merely the storage tank, although for treatment of tanks only, water-bottom biocides may be used and this will be a cheaper option, since the volume to be treated is smaller. Some of the available biocides are shown in Table 4 . The required properties are frequently obtained by biocide formulation, rather than being inherent to the chemical compound itself.

Table 4 - Examples of oil- and water-soluble biocides.

\begin{tabular}{ll}
\hline Oil soluble & Water soluble \\
\hline Isothiazolone formulations & Morpholines \\
Organoborinanes & Oxazolidines \\
Pyridinethione & Halides \\
Hexahydrotriazines & Aldehydes \\
Imidazolcarbamate & Phenolics \\
\hline
\end{tabular}

Shennan (38) lists 4 categories of biocide product for use in fuel/water systems:-

- oil-dispersible products partitioning completely into the water phase, for treatment of water bottoms

- oil-soluble products which partition into the aqueous phase for use in clean fuels where little water is expected

- oil-soluble blends, separating into 2 components, one active in the water and the other in the oil, for protecting the interface and the water bottom

- water-soluble products for addition to tank bottoms.

Bento and Gaylarde (5) tested 4 biocides for their activity in oil/water systems against bacteria and fungi isolated from diesel fuels. An isothiazolone mixture and a quaternary ammonium compound were the most effective, glutaraldehyde and a formaldehydereleasing agent being active only at relatively high concentrations, if at all. The most resistant organisms were bacteria of the genus Bacillus, the most sensitive isolate of which was inhibited, but not killed within $24 \mathrm{~h}$, by $50 \mathrm{ppm}$ isothiazolone (the highest concentration tested). Guiamet and Gaylarde (17) demonstrated that the same isothiazolone mixture was active against biofilms of $H$. resinae at 50ppm, but was much less effective when SRB were also present on the metal surface. The need to consider biofilm organisms is highlighted by the example quoted in Hill and Hill (26), in which seizure of all pumps and injectors on a small cargo ship was treated by physical cleaning, but no biocide addition. Hence some microorganisms remained attached to the walls of the system, with the result that the same problem recurred 2 months later when the vessel was at sea!

\section{Costs of biocide treatment}

These have been calculated at around US $\$ 3$ per ton of fuel for decontamination and US\$0.4 - 0.8 for 
continuous preventative treatment (26). An unknown factor is the potential for resistance development of the contaminating microorganisms, which will necessitate the use of more than one biocide type. Although there are no reports in the literature of such developed resistance, it has been noted in fuel systems (Hettige, personal communication) and this highlights the need for routine microbiological monitoring. This may increase the overall costs, but reduces the risk of expensive, ineffective, treatment.

\section{Environmental considerations}

Biocides, by their nature, are toxic and may present a hazard to the fuel handlers, to personnel working in areas where fuel volatilization may occur and to organisms in the environment receiving wastes from the system. Thus their use should be restricted and their disposal monitored. If sufficient dilution is not achieved on disposal, then a chemical inactivator may have to be used. Although excessive use of biocides should be avoided, their utilization should be recommended to reduce the possibility of fuel leakage to the environment through microbially corroded pipes and tanks and to try to eliminate the need for disposal of large volumes of contaminated, unusable products.

\section{CASE HISTORY}

Many of the points discussed above are illustrated by the following example.

In 1995, UFRGS undertook an investigation on behalf of a company manufacturing engine parts. Increased wear and breakages were occurring in vehicles of bus companies in the south, south-east and central-west of Brazil, where a new type of additive had recently been introduced into the diesel. The companies were visited and details of routine maintenance procedures and perceived problems noted. Samples of fuel were collected from representative parts of the system for microbiological analysis.

Most companies did not have well defined routines for maintenance of their diesel storage systems. In some cases, tanks were drained to remove water every 15 days, in others the foreman seemed unaware of the necessity to drain tanks. A typical biomass was found in some storage tanks, accompanied by an aqueous phase of low $\mathrm{pH}$ (3-5). Poorly maintained storage systems were characterized by frequent need to change filters, both in the storage system and in the vehicles, and reduced engine efficiency. Increased replacement of fuel nozzles was also noted, a problem linked by other workers to microbial contamination (19).

The most significant organisms isolated were $H$. resinae and $\mathrm{SRB}$, isolated from storage tanks, filters and tanks containing filtered fuel. No SRB were found in the vehicle tanks or injectors, where no water-phase was present, but bacteria of the genus Bacillus were frequently encountered at all the points sampled.

It was not possible to correlate the level of microbial contamination with premature failure of engine parts, but there was a relationship between the latter and the use of the new additive. However, the additive was later shown not to promote microbial growth in laboratory studies (6).

An important fact indicated by many of the companies was the decrease in vehicle maintenance problems following the replacement of underground storage tanks by aerial systems. One firm in Rio Grande do Sul was loosing considerable quantities of fuel through highly corroded in-ground storage tanks (and hence causing unknown pollution of the surrounding area). The tanks were replaced by an aboveground system with storage tanks inclined at $30^{\circ}$ to the horizontal to facilitate water drainage and removal, resulting in a better-maintained system and fewer problems. Currently, biocides are not used by these companies, but the Brazilian petroleum company, Petrobrás, has carried out tests on lorries and diesel storage tanks to show that considerable reductions in microbiological problems can be achieved by the use of isothiazolones (37). A program of education for garage foremen has been undertaken by the Microbiological Resources Center (MIRCEN) in Porto Alegre, in an attempt to reduce both economic losses to the firms and environmental pollution caused by hydrocarbon seepage. The First Seminar on Storage of Diesel Oil took place in December, 1997, and others are planned for the future. Without doubt, the dissemination of information is the most important activity for the avoidance of the economic and environmental problems associated with diesel oil storage.

\section{RESUMO}

\section{Contaminação microbiana de combustíveis hidrocarbonados e o seu controle}

O problema microbiano maior na indústria de refino de petróleo é a contaminação de produtos armazenados, que pode levar à perda da qualidade, à formação de borra 
e à deterioração de tubulações e tanques de estocagem, na refinaria e no usuário. São abordadas, neste artigo, três classes de combustível, gasolina, querosene de aviação e óleo diesel, correspondente à ordem crescente de peso no fracionamento de petróleo. $\mathrm{O}$ óleo diesel apresenta os problemas microbiológicos mais sérios. São relatados os diversos microrganismos isolados de sistemas de combustíveis hidrocarbonados. São apresentadas as condições necessárias para crescimento microbiano e os métodos utilizados para o monitoramento e controle desse crescimento. Os efeitos de diversos aditivos, inclusive biocidas, são discutidos

Palavras chave: biocidas; biofilmes; combustíveis hidrocarbonados; corrosão microbiana; tanques de estocagem

\section{REFERENCES}

1. Allsopp, D. and Seal, K.J. Introduction to Biodeterioration, Edward Arnold, London. 1986

2. Anon. An analysis of certain microbiological matter in aircraft fuels. Technical report of Shell Intl., London, 1961.

3. Bailey, C.A. and May, M.E. Evaluation of microbiological test kits for hydrocarbon fuel systems. Appl. Environ. Microbiol., 37: 871-877, 1979

4. Batts, B.D. and Fathomi, A.Z. A literature review on fuel stability studies with particular emphasis on diesel oil. Energy and Fuels, 5: 2-21, 1991

5. Bento, F.M. and Gaylarde, C.C. Microbial contamination of stored diesel oil in Brazil. Rev. Microbiol., 27: 192-196, 1996.

6. Bento, F.M. and Gaylarde, C.C. Effect of additives on fuel stability - a microbiological study. In: LABS 3 - Third Latin American Biodegradation and Biodeterioration Symposium, eds. C.C. Gaylarde, T.C. Barbosa and N.H. Gabilan, The British Phycological Society, UK, paper no. 10, 1998.

7. Cabral, D. Corrosion by microorganisms of jet aircraft integral fuel tanks. Part 1.: Analysis of fungal contamination. Internat. Biodeter. Bull., 16: 23-27, 1980.

8. Cafone, L. (Jn), Walker, J.D. and Cooney, J.J. Utilization of hydrocarbons by Cladosparium resinae. J. Gen. Microbiol. 76, 243-246, 1973.

9. Campos A.C., Lemmers H., Bieler R.A. Ensaios realizados em derivados de petróleo: Significado e interpretação. Petróleo e Petroquímica, 16/17:12-14, 1974a.

10. Campos A.C., Lemmers H., Bieler R.A. Ensaios realizados em derivados de petróleo: Significado e interpretação. Petróleo e Petroquímica, 18/19:17-20, 1974b.

11. Davis, J.B. Petroleum Microbiology. Elsevier, Amsterdam, 1967.

12. Fass, R., Ben-Asher, J. and Shavit, A.B. Effects of microbial contamination in storage tanks on the long-term stability of jet fuel. In Proc. 2nd Internat. Conf. on Long Term Stabilities of Liquid Fuels, ed. L.L. Stavinoah, SRI, San Antonio, Tx, 1986 , pp. 253-263.

13. França, F.P., Sérvulo, E.F.C., Lutterbach, M.T.S. and Barbosa, G.M. The detection of microorganisms present in deteriorated diesel oil. In FIRST LABS, eds. W.C. Latorre and C.C. Gaylarde, TecArt Editora, São Paulo, 1992, pp. 65-68.
14. Francis D.E.II. Effects of unstable and microbially contaminated fuel on vehicle operations: a diesel fuel preventive maintenance program. ASTMSTP 1005, 1988, pp 157-166.

15. Gardner, A.C. and Williams, G.R. The growth of Pseudomonas putida in fuel samples containing 2-methoxyethanol (2-ME). Internat. Biodeter. Bull., 3: 93-94, 1982.

16. Gaylarde, C.C. Microbial corrosion of metals. Environmental Engineering, December, 1989, 1989, pp. 30-32.

17. Guiamet P. and Gaylarde C.C. Activity of an isothiazolone biocide against Hormoconis resinae in pure and mixed biofilms. World J. Microbiol. Biotechnol., 12: 395-397, 1996.

18. Gutheil, N.G. Ocorrência de Cladosporium resinae (Lindau) de Vries em querosene de aviação no Brasil. Boletim No. 9, Instituto Tecnolólogico do RS, Porto Alegre, 1966.

19. Haggatt R.D. and Morchat, R.M. Microbiological contamination: biocide treatment in naval distillate fuel. Internat. Biodeter. Biodeg., 29: 87-99, 1992.

20. Hartman, J., Geva, J. and Fass, R A. computerized expert system for diagnosis and control of microbial contamination in jet fuel and diesel fuel storage systems. In 4th Intl. Conf. on Stability and Handling of Liquid Fuels, Orlando, Fa, Nov. 19-22, 1991, pp. $153-166$.

21. Hendey, N.I. Some observations on Cladosporium resinae as fuel contaminant and its possible role in the corrosion of aluminium alloy fuel tanks. Trans. Brit. Mycol. Soc., 47: 467-475, 1964.

22. Herbert, B.N., Hill, E.C., Oates, P.D., Powell, D., Shennan, J.L. and Whittle, R. A method for testing light distillate fuels. In: Industrial Microbiological Testing, eds. J. Hopton and E.C. Hill, London: Blackwell Scientific, 1987, pp. 215-219.

23. Hettige, G.E.G. and Sheridan, J.E. Interactions of fungi contaminating diesel fuel oil. Internat. Biodeter. 25: 299-316, 1989.

24. Hettige, G.E.G. and Sheridan, J.E. The mycoflora in aviation and diesel fuel. In Recent Advances in Biodeterioration and Biodegradation, Vol. II, eds. K.L. Garg, N. Garg and K.G. Mukerji, Naya Prokash, Calcutta, 1994, pp. 17-29.

25. Hill, E.C. Fuels. In Microbial Problems in the Offshore Oil Industry, eds. E.C. Hill, J. Shennan and R. Watkinson, Wiley, New York, 1987, pp. 219-230.

26. Hill, E.C. and Hill, G.C. Microbiological problems in distillate fuels. Trans. Inst. Marine Eng., 104: 119-130, 1993.

27. Irish, G.E. and Richardson, R.L. ASTM STP 751, 76-83, 1981

28. Litman, E.S. Microbiological contamination of fuels during storage. In Distillate Fuel Stability and Cleanliness, eds. L.L. Stavinoah and E.I. Henry, ASTM 04-751000-12, 1980, pp. 136-144.

29. Lopes, P.T.C. and Gaylarde, C.C. Use of immunofluorescence to detect Hormoconis resinae in aviation kerosine. Internat. Biodeter. Biodeg.,37: 37-40, 1996.

30. Miyoshe, M. Die Durchbohung von Membranen durch Pfilzfaden. Jahrbuch für Wissenschaftliche Botanik, 28: 269$289,1985$.

31. Morgan, P. and Watkinson R.J., Biodegradation of components of petroleum. In.Biochemistry of Microbial Degradation, eds. Ratledge, C. Kluwer Academic Publishers, Dordrecht, 1994, pp 1-31.

32. Neihof, R.A. and Bailey, C.A. Biocidal properties of anti-icing additives for aircraft fuels. Appl. Environ. Microbiol., 35: 698$703,1978$.

33. Neihof, R.A.and May, M. Microbial and particulate contamination in fuel tanks on naval ships. Internat. Biodeter. Bull. 19: 59-68, 1983.

34. Parbery, D.G. Isolation of the kerosene fungus Cladosporium resinae, from Australian soil. Trans Brit. Mycol. Soc. 50, 682685, 1967.

35. Pitcher, D.G. Industrial case histories of microbiological fuel contamination - cause, effect and treatment. Internat. Biodeter., $25: 207-218,1988$. 
36. Reddy, S.R. Fuel filter plugging by insoluble sediment in diesel fuels. In Distillate Fuel: Contamination, Storage and Handling, eds. H.L. Chesneau and M.M. Dorris, ASTM STP 10005, Philadelphia, 1988, pp. 82-94.

37. Rodrigues, E.G.C., Scotfield, A.L., Menezes, E.P., Santa Anna, L.M.M., Furtado, M.A.L., Rocha, M.Y. and Yuan, V. Evaluation of microbial contamination and control in diesel oil. In LABS 2. Biodeg. Biodeter. Latin America. eds. C.C. Gaylarde, E.L.S. de Sá and P.M. Gaylarde, 1996, pp.35-37.

38. Shennan, J.L. Control of microbial contamination of fuels in storage. In Biodeterioration 7, eds. D.R. Houghton, R.N. Smith and H.O.W. Eggins, Elsevier, Barking, 1988, pp. 248-254.

39. Smith, R.N. Fuel testing. In: Microbiology of Fuels, ed. R.N. Smith, London, Inst. Petrol., 1987, pp. 49-54.

40. Smith, R.N. Bacterial extracellular polymers: a major cause of spoilage in middle distillate fuels. In: Biodeterioration 7, eds D.R. Houghton, R.N. Smith, H.O.W. Eggins, Barking: Elsevier, 1988, pp. 256-262.

41. Smith, R.N. Developments in fuel microbiology. In Biodeterioration and Biodegradation 8, ed. Rossmoore, H.R., London: Elsevier, 1991, pp. 112-124.

42. Smith, R.N. and Crook, B. The germination and growth of Cladosporium resinae in fuel oil. In Biodeterioration 4, eds. T.A. Oxley and G. Becker, Pitman, London, 1980, pp. 29-36.

43. Smith, R.N. and Maw, J.M. The bridge slide culture technique for fungicide studies in fuel oil. In Industrial Microbiological Testing, eds. J. Hopton and E.C. Hill, Blackwell, Oxford, 1987, pp. 243-245.

44. Solana, M.J.V. and Gaylarde, C.C. Contaminação microbiana de hidrocarbonetos no Rio Grande do Sul. In. FIRST LABS, eds. W.C. Latorre and C.C. Gaylarde, TecArt Editora, São Paulo, 1992, pp. 61-64.

45. Solana, M.J.V. and Gaylarde, C.C. Fungal contamination and growth in various hydrocarbon fuels. In Biodeterioration and Biodegradation 9, eds. E. Bousher, M. Chandra and R. Edyvean, Rugby: Inst. Chem. Engs., 1995, pp. 621-628.
46. Stockdale, H. and Watkinson R.J. Review of rapid techniques for estimating organisms in petroleum products. In Rapid Methods for the Diagnosis of Microbial Problems in the Petroleum Industry. Wilkinson R.J. (ed) Institute of Petroleum London, 1989, pp 1-20.

47. Teh, J.S. and Lee, K.H. Utilization of n-alkanes by Cladosporium resinae. Appl. Microbiol. 25:454-457, 1973.

48. Turner, A.P.F., Eaton, R.A. and Jones, E.B.G. Nutritional aspects of ship fuel system contamination by Cladosporium resinae. In: Biodeterioration 5, eds. T.A. Oxley and S. Barry, London, Wiley and Sons, 1983, pp. 507-516.

49. Valle, S.M. and Videla, H.A. Biocorrosão de alumínio 2024 e biodeterioração de combustível por contaminantes fúngicos. In: FIRST LABS, eds. W.C. Latorre and C.C. Gaylarde, São Paulo, TecArt Editora, 1992, pp. 192-199.

50. Videla, H.A. Corrosão Microbiológica. Edgard Blücher, São Paulo, 1981

51. Videla, H.A. Electrochemical interpretation of the role of microorganisms in corrosion. In Biodeterioration 7, eds. D.R. Houghton, R.N. Smith and H.O.W. Eggins, Elsevier, Barking, 1987,pp. 359-371.

52. Wasko, M.P. and Bratt, R.P. Properties of a biosurfactant produced by the fuel contaminant Ochrobactrum anthropii. Internat. Biodeter., 27: 265-273, 1990 .

53. Watkinson, R.J. and Morgan, P. Physiology of aliphatic hydrocarbon-degrading microorganisms. Biodegradation 1: 7992, 1990 .

54. Westbrook S.R., Stavinoha L.L., Barbee J.G. and Bundy L.L. In Proc. 2nd Intl. Conf. on Long Term Storage Stabilities of Liquid Fuels, ed. L.L. Stavinoah, 1988, pp. 111-124.

55. Williams, G.R. and Lugg, M. The significance of bacteria in aviation turbine fuel containing anti-icing additive. Internat. Biodeter. Bull. 16: 103-105, 1980. 